\title{
Hidradenitis suppurativa: retrospective study of 20 cases $^{*}$
}

\author{
Hidradenite supurativa: estudo retrospectivo de 20 casos
}

\author{
Nurimar Conceição Fernandes \\ Cíntia Maria O. Lima²
}

\author{
Camilla Pimentel A. Franco²
}

\begin{abstract}
In this study, twenty cases of severe hidradenitis suppurativa are reported, mainly in non-white people and in axillary areas. Wide surgical excision has offered good results, although relapses have occurred at variable intervals in the follow-up period.

Keywords: Diagnosis; Hidradenitis suppurativa; Pathology; Radiotherapy; Surgical procedures, operative

Resumo: São relatados 20 casos de hidradenite supurativa grave, com predomínio de não brancos e regiões axilares. A excisão cirúrgica ampla trouxe bons resultados, embora a recidiva ocorresse em intervalos variáveis no acompanhamento.

Palavras-chave: Diagnóstico; Hidradenite supurativa; Patologia; Procedimentos cirúrgicos operatórios; Radioterapia
\end{abstract}

Hidradenitis suppurativa is a suppurative and chronic disease, located mainly in areas with apocrine glands, which affects adults of both genders with no racial predisposition. Genetic predisposition and hormonal influence are described, but its pathogenesis is not precisely known. ${ }^{1,2}$ An observational retrospective study (1978 to 2010) was conducted in a dermatology ward. The study included nine men (four white/ five non-white) and eleven women (three white/ eight non-white) aged 30 to 49 years in half the cases. The locations included the axillary area (five cases); inguinal and axillary regions (four); gluteal and perineal/perianal areas (four); axillary, gluteal, perineal, and inguinal regions (five); gluteal and perineal areas (two cases). Alcoholism and smoking were detected in eight cases, obesity in seven, and smoking in five.
All cases were biopsied and showed a chronic suppurative inflammatory pattern, as well as epithelioid cell granulomas and foreign-body giant cells.

The reason for admission was a formal surgical indication in all cases due to gravity, long duration of the disease (from months to 20 years), clinical status, degree of skin involvement, complications of the disease, and clinical treatment failure (topical and systemic antibiotics, intralesional corticoids, oral isotretinoin). ${ }^{3,45}$ Surgery consisted of excision of the affected area and repair with grafts and skin flaps.

Routinely, 14 days before surgery, patients were administered oral prednisone at a dose of $40 \mathrm{mg} /$ day (without weaning later), enabling the surgeon to better handle the injuries by reducing the inflammatory component. Although there was visible improvement

Approved by the Advisory Board and accepted for publication on 19.07.2012.

* Work conducted at the Department of Dermatology / Pathology Anatomy and Plastic Surgery - HUCFF/UFRJ - Rio de Janeiro, Brazil.

Conflict of interest: None

Financial funding: None

Associate Professor, School of Medicine / Federal University of Rio de Janeiro (Universidade Federal do Rio de Janeiro/UFRJ); Department of Dermatology, Hospital Universitario Clementino Fraga Filho (HUCFF/UFRJ) - Rio de Janeiro, Brazil.

Specialization in Dermatology, Department of Dermatology, HUCFF/UFRJ Department of Dermatology, Hospital Universitário Clementino Fraga Filho (HUCFF/UFRJ) - Rio de Janeiro, Brazil. 
in quality of life, all patients relapsed at varying intervals (1-2 years).

In a patient with dilated cardiomyopathy, for whom extensive surgery was contraindicated (buttocks and inner thighs), radiation therapy successfully controlled the disease. In an HIV-positive patient, surgery (inguinal, perineal, and gluteal areas) was rejected. Radiotherapy was initiated as an alternative therapy, but in the eighth session the patient progressed to a genital herpes infection. Radiotherapy was stopped and acyclovir was started.

It was considered an appropriate option, since biological therapy showed minimal evidence of clinically significant efficacy. ${ }^{6,7}$

\section{REFERENCES}

1. Reyuz J. Hidradenitis suppurativa. J Eur Acad Dermatol Venereol. 2009;23:985-98.

2. Slade DE, Powell BW, Mortimer PS. Hidradenitis suppurativa: pathogenesis and management. Br J Plast Surg. 2003;56:451-61.

3. Sehgal VN, Verma P, Sawant S, Paul M. Contemporary surgical treatment of hidradenitis suppurativa (HS) with a focus on the use of the diode hair laser in a case. J Cosmet Laser Ther. 2011;13:180-90.

4. Menderes A, Sunay 0, Vayvada H, Yilmaz M. Surgical management of hidradenitis suppurativa. Int J Med Sci. 2010;7:240-7.

5. Pironi D, Caruso F, Panarese A, Venderttuoli M, Mascagni D, Moraldi L, et al. Chronic hidradenitis suppurativa in the inguinal, perineal and scrotal regions. $A$ case report and review of the literature. Ann Ital Chir. 2010;81:465-70.
The efficacy of radiotherapy in the treatment of hidradenitis suppurativa has been evaluated in 231 patients, with total doses between 3.0 and $8.0 \mathrm{~Gy}$. In chronic and recurrent cases, two or more series with a total dose of 10.0 Gy were administered. ${ }^{8}$ In 40 percent of cases, there was improvement of symptoms; in 38 percent of cases, there was complete relief of symptoms. Only two patients did not respond to therapy.

The conclusions of the present study are: (1) clinical treatment in the early stages of the disease produces transient results; (2) the radical excision of tissues, including the apocrine glands, is the definitive treatment, and (3) in cases of long evolution, surgical treatment does not prevent recurrence..$^{1-5}$
6. Frohlich D, Baaske D, Glatzel M. Radiotherapy of hidradenitis suppurativa--still valid today ? Strahlenther Onkol. 2000;176:286-9.

7. Obadia DL, Daxbacher ELR, Jeunon T, Gripp AC. Hidradenitis suppurativa treated with infliximab. An Bras Dermatol. 2009;84:695-7.

8. Lee RA, Dommasch E, Treat J, Sciacca-Kirby J, Chachkin S, Williams J, et al. A prospective clinical trial of open-label etanercept for the treatment of hidradenitis suppurativa. J Am Acad Dermatol. 2009;60:565-73.

\author{
MAILING ADDRESS: \\ Nurimar Conceição Fernandes \\ Rua Alexandre de Gusmão, 28 - 201 \\ 20520-120 Rio de Janeiro, RJ. \\ Brazil \\ E-mail: nurimarfernandes@terra.com.br
}

How to cite this article: Fernandes NC, Lima CMO, Franco CPA. Hidradenitis suppurativa: retrospective study of 20 cases. An Bras Dermatol. 2013;88(3):480-1. 